\title{
1 Nitrogen deposition and plant biodiversity: past, present, and future
}

2 Richard J Payne ${ }^{1 *}$, Nancy B Dise ${ }^{2 *}$, Christopher D Field ${ }^{3}$, Anthony J Dore ${ }^{2}$, Simon J M Caporn ${ }^{3}$, Carly J

3 Stevens $^{4}$

41 Environment Department, University of York, Heslington, York, YO10 5DD, United Kingdom.

52 Centre for Ecology and Hydrology- Edinburgh, Bush Estate, Penicuik, Midlothian, EH26 0QB, United

6 Kingdom.

73 School of Science and the Environment, Manchester Metropolitan University, Chester Street,

8 Manchester, M1 5GD, United Kingdom.

94 Lancaster Environment Centre, Lancaster University, Bailrigg, Lancaster, LA1 4YQ, United Kingdom.

10 *Joint First Authors. E-mail: richard.payne@york.ac.uk; nadise@ceh.ac.uk

11

12 KEYWORDS: Vegetation; Global change; Air pollution; Species richness 
Reactive nitrogen $(\mathrm{N})$ deposition from intensive agricultural and industrial activity has been identified as the third greatest threat to global terrestrial biodiversity. While the impacts of $\mathrm{N}$ deposition are widely accepted, their magnitude is poorly quantified. Here we combine $\mathrm{N}$ deposition models, empirical response functions and vegetation mapping to model the impacts of $\mathrm{N}$ deposition on plant species richness from 1900 to 2030 using Great Britain as a case study. We find that $\mathrm{N}$ deposition is likely to have caused the loss of approximately one-third of species richness from five widespread habitats. Our results suggest that currently-expected reductions in the emission of $\mathrm{NO}_{\mathrm{y}}$ and $\mathrm{NH}_{3}$ will achieve no more than modest increases in species richness by 2030 and that cuts based on habitat critical loads may be inefficient. The impacts of $\mathrm{N}$ deposition on plant biodiversity are severe and unlikely to be quickly reversed. 
37

The recently-adopted UN Sustainable Development Goals (SDGs) include a target to halt biodiversity loss from terrestrial ecosystems by 2030. An important but frequently-overlooked threat to global biodiversity is deposition of reactive nitrogen $(\mathrm{N})$, produced by fossil fuel combustion and intensive agriculture. Since many ecosystems have evolved under conditions of $\mathrm{N}$ limitation, a long-term increase in $\mathrm{N}$ deposition at even low levels can cause eutrophication and acidification with wideranging impacts on ecosystem services and biodiversity. Field and laboratory experiments and surveys repeated through time and across pollution gradients have conclusively shown that longterm elevated $\mathrm{N}$ deposition (comprising wet-deposited $\mathrm{NH}_{4}{ }^{+}$and $\mathrm{NO}_{3}{ }^{-}$and dry-deposited $\mathrm{NH}_{3}$ and $\mathrm{NO}_{\mathrm{y}}$ ) is linked to reduced plant biodiversity in many natural ecosystems (Dise, et al. 2011, Duprè, et al. 2010, Maskell, et al. 2010). Excess N impacts plants through direct toxicity, soil acidification, nutrient imbalances, and interspecific competition (Dise, et al. 2011). Loss of plant biodiversity is known to impact on microbial and faunal biodiversity through trophic cascades and to lead to an erosion of important ecosystem services (Erisman, et al. 2013, RoTAP 2012, Sutton, et al. 2011). National and trans-national policy requires this threat to be addressed (DEFRA 2011, United Nations 2015) but the scale of impacts at regional to national scales has not been quantified and we have little understanding of how impacts have arisen through time and may develop in the future.

In many regions of the developed world levels of $\mathrm{N}$ deposition are expected to plateau and decline in coming decades and a key question is how this will affect biodiversity (Lamarque, et al. 2013, Sutton, et al. 2011). Studies of recovery from decreased $\mathrm{N}$ deposition are limited (Tilman and Isbell 2015), but available evidence suggests three main trajectories. Some impacts of $\mathrm{N}$ may be acute and linked to atmospheric concentrations, for instance direct damage by gaseous ammonia (Carfrae, et al. 2004). Recovery from such impacts may be relatively rapid, with the degree of recovery proportional to the deposition reduction. Other impacts may develop more gradually with the long-term accumulation of $\mathrm{N}$ in soil causing ecological changes such as competitive shifts in species abundance. Recovery from these impacts will be slower, requiring the removal of stored $\mathrm{N}$ from the system by processes such as denitrification, leaching, fire, or harvesting (Dise, et al. 2011). There may be considerable hysteresis in ecological recovery due to factors such as species dispersal abilities and the loss of seedbank (Basto, et al. 2015). Most concerningly, chronically elevated $\mathrm{N}$ deposition may cause a regime shift with the establishment and invasion of nitrophilic species which then selfperpetuate through mechanisms such as shading, litter accumulation, and allelopathy (Isbell, et al. 2013). Such regime shifts may be essentially irreversible on human timescales. Which of these trajectories will dominate is unclear and this is likely to vary between habitats and sites.

Great Britain (GB) has been a model for studies of pollution impacts for many years as early industrialisation means that impacts here can often provide early-warning of impacts developing elsewhere. As an exemplar region, GB also benefits from intensively studied vegetation communities, air pollution gradients that encompass the range across most of the developed world, and an extensive air quality monitoring network. UK domestic environmental policy goes beyond the requirements of the SDGs, with aims to both halt biodiversity loss earlier than the UN goal and, ultimately, to reverse previous losses (DEFRA 2011). Here we use models based on well-established empirical relationships to investigate the potential impacts of $\mathrm{N}$ deposition on landscape-scale biodiversity in the past, present and future. 
We focus on the species richness of five habitats that are widespread in the temperate and subboreal zone and known to be sensitive to nitrogen deposition: acid grassland, bog, sand dune, upland heathland and lowland heathland (Bobbink, et al. 2010). These habitats have all been surveyed across GB-wide nitrogen deposition gradients in previous studies. These studies showed species richness to be significantly negatively related to $\mathrm{N}$ deposition after accounting for other major drivers on diversity that were measureable at that scale (Field, et al. 2014, Stevens, et al. 2004). The identified relationships are supported by a large body of other research and are used here as the best-available basis for spatial and temporal up-scaling (Duprè, et al. 2010, Maskell, et al. 2010, Payne, et al. 2014).

We modelled the change in $\mathrm{N}$ deposition from 1900 to 2030 using the UK's national air pollution models C-BED (Smith, et al. 2000) and FRAME (Dore, et al. 2007) with scaling factors for historic emissions (Fowler, et al. 2005). We defined four scenarios of future $\mathrm{N}$ deposition: current expectations (CE) based on trends in industrial and agricultural activity anticipated by the UK government; ten (\%10) and thirty (\%30) percent blanket deposition reductions beyond CE; and a scenario in which local action is taken to reduce deposition to the legally-mandated target (critical load: CL) for each grid cell (Bobbink and Hettelingh 2011).

To reflect the considerable uncertainty in how $\mathrm{N}$ impacts biodiversity and how species richness will recover from reduced deposition we propose three alternative scenarios spanning the range of possibilities suggested in the literature. In the first scenario, increases in $\mathrm{N}$ deposition will produce an instant loss of species richness and reductions in $\mathrm{N}$ deposition will produce instant recovery. We reflect this scenario by using current-year annual $\mathrm{N}$ deposition as the driver of species richness change. In the second scenario, increases and decreases in $\mathrm{N}$ will produce lagged responses as species richness takes time to respond to $\mathrm{N}$ deposition due to ecological hysteresis and accumulated $\mathrm{N}$. We reflect this scenario by using a 30 year moving window of $\mathrm{N}$ deposition as the driver of species richness change (Rowe, et al. 2016). Finally we consider the possibility that the impacts of $\mathrm{N}$ may be irreversible on decadal time-scales as communities undergo fundamental regime shifts. We reflect this scenario by using cumulative $\mathrm{N}$ deposition since 1900 as the driver of species richness change. While all of these scenarios are feasible, we consider the lagged scenario to be perhaps the most plausible (Rowe, et al. 2016). We used regression to model the relationship between species richness and each metric of $\mathrm{N}$ deposition in the national surveys (current/fully cumulative/30 year cumulative), representing each of the three response scenarios. We quantified the spatial distribution of the five target habitats using data from the UK National Vegetation Classification dataset (Averis 2004). Applying the regression equations to the $\mathrm{N}$ deposition trajectories for each $10 \times 10 \mathrm{~km}$ cell containing a specific habitat allowed us to predict change in species richness due to $\mathrm{N}$ deposition over time (WebFigure 1). We expressed the output as a percentage relative to the maximum species richness in the absence of $\mathrm{N}$ deposition (i.e. the $\mathrm{Y}$-intercept) and summed results across habitats and grid cells to assess impacts across Great Britain (see Supplementary Methods for full detail). 
118 We find that, across habitats and regardless of the response scenario chosen, modelled species richness for 2015 is approximately two thirds of species richness in the absence of $\mathrm{N}$ deposition (range 65-68\%; Fig. 1). The largest loss, with species richness around $25 \%$ of 1900 levels, is in the south of Britain, coinciding with the highest levels of $\mathrm{N}$ deposition. Acid grassland and upland heath are the most impacted communities; bogs show the lowest loss of species richness (WebFigure 2).

123

All models show species richness declines due to $\mathrm{N}$ deposition from 1900 through to the late $20^{\text {th }}$ century (Figure 2). The instant response scenario shows species richness at the start of the $20^{\text {th }}$ century to be around three quarters of the 'no $\mathrm{N}$ deposition' baseline (due to existing industrial emissions) followed by a steady decline to the 1990s and then some recovery. Models based on cumulative $\mathrm{N}$ impacts, by contrast, show species richness gradually declining as $\mathrm{N}$ accumulates in the system over time, with no recovery. Results from models based on 30-year cumulative $\mathrm{N}$ deposition impacts (where, by definition, responses cannot be modelled until 1930) are between these extremes. Under all response scenarios, the decline in species richness through the twentieth century considerably exceeds estimated errors based on $95 \%$ confidence intervals of the underlying regressions. The timing and extent of recovery differs for the different scenarios: under the assumption of instant ecosystem response to $\mathrm{N}$ deposition, recovery begins at the end of the $20^{\text {th }}$ century as $\mathrm{N}$ deposition declines, assuming a 30-year lagged response to $\mathrm{N}$ deposition, impacts increase to the end of the $20^{\text {th }}$ century and then stabilise, and assuming the response is to cumulative $\mathrm{N}$ deposition, species richness continues to decline through to 2030 (Fig. 2; WebFigure 3; WebVideo File).

\section{DISCUSSION}

If, as expected, these habitats are representative of $\mathrm{N}$-sensitive ecosystems, and defining biodiversity simply as total plant species richness, it is only under the most extreme assumption of fully-cumulative impacts of nitrogen on species that the UK will fail to meet the SDG target to halt biodiversity loss due to $\mathrm{N}$ deposition. Other developed countries are likely to follow similar trajectories by reducing $\mathrm{N}$ emissions. All models agree that currently-expected $\mathrm{N}$ emission reductions will not lead to species richness returning to levels of the early $20^{\text {th }}$ century by 2030 . The scale of further deposition cuts that would be required to achieve levels of species richness last seen in the early $20^{\text {th }}$ century (1900-1940 mean) ranges from very large (27.3\% cut) for the optimistic instant impact/instant recovery scenario, to vast (92\%) for the 30 -year lagged impact/lagged recovery. Due to the non-linear relationship between $\mathrm{N}$ emission and $\mathrm{N}$ deposition, achieving such large deposition reductions might require even larger emission reductions (RoTAP 2012). Clearly this scale of deposition reduction is highly unlikely to be achieved, and therefore the loss of species richness is unlikely to be substantially reversed. The most pessimistic possibility is that no extent of $\mathrm{N}$ deposition cuts will lead to the recovery of habitats which have undergone fundamental regime shifts, as shown by the cumulative impact/no recovery scenario. However the most likely outcome is probably only a very modest improvement in GB-wide species richness of the five habitats by 2030 (e.g. $3 \%$ average increase in species richness with currently expected emissions reductions and the 30-year lagged response scenario). Similarly limited recovery is likely in other countries where deposition has peaked. $\mathrm{N}$ impacts however are likely to extend into previously-unimpacted regions of the world partly due to the export of industrial and agricultural $\mathrm{N}$ emissions from the developed world. Achieving the SDG target in terms of Nitrogen deposition is likely to be extremely challenging. 
The main policy tool used to control air pollution in Europe, and increasingly the rest of the world, is the critical load: a level of pollution loading below which impacts on a specified habitat type are not known to occur (Bobbink and Hettelingh 2011). Critical loads are assigned on the basis of experimental studies and expert opinion, but both the existence of an 'impact floor' and the ranking of ecosystem sensitivity have recently been questioned for some habitats (Armitage, et al. 2014, Field, et al. 2014, Payne, et al. 2013). In our models one surprising finding is that blanket cuts in $\mathrm{N}$ deposition across Britain achieve a higher GB-wide recovery of species richness than the same overall reduction of $\mathrm{N}$ deposition based on the lowest critical load for each grid cell (WebTable 1 ). This is because the survey data that underlie our models do not support the ranking of habitat sensitivity used by critical loads (Field, et al. 2014). This may give caution to the use and wider adoption of this approach. However it should be noted that critical loads are not used solely for the preservation of plant biodiversity and there are other applications (e.g. ecosystem biogeochemical changes) for which targeted reduction in $\mathrm{N}$ deposition on the basis of critical loads may be more effective.

Large reductions in $\mathrm{N}$ deposition are achievable. For instance, the Netherlands has halved ammonia emissions since 1990, primarily by requiring better agricultural technology (Sutton, et al. 2015). In the United Kingdom, measures such as improvements in manure spreading, manure storage and livestock management have the potential to make a substantive difference for comparatively modest investment (Dragosits 2015). Similarly, there may be a role for active habitat management to remove accumulated $\mathrm{N}$ (e.g. burning, grazing, turf cutting) and thereby accelerate recovery (Jones, et al. 2017, Storkey, et al. 2015). Enforcing such options would require considerable political will and funding. Policy-makers often look for rapid 'quick-win' results, but our models demonstrate that it is likely to take considerable time for the ecological benefits of reduced $\mathrm{N}$ deposition to be realised. There is therefore a key role for appropriate mid-point metrics such as reductions in $\mathrm{N}$ leaching or tissue $\mathrm{N}$ content, to allow the long-term benefits of $\mathrm{N}$ deposition reduction to be communicated on political time-scales (Rowe, et al. 2016). Our results demonstrate the large scale of the $\mathrm{N}$ deposition problem, which has built up over many years and over extensive regions, and show that positive outcomes for biodiversity of reducing $\mathrm{N}$ deposition are unlikely to be achieved quickly. 
Research was funded by the United Kingdom Natural Environment Research Council through the European Union FP6 BiodivERsA (ERA-NET) project PEATBOG (Pollution, Precipitation and Temperature Impacts on Peatland Biodiversity and Biogeochemistry). Thanks to all who contributed to the datasets we use here, including the Terrestrial Umbrella project partners, and all who assisted with data collection and provided access permission for sites. Thanks to Laurence Jones for providing additional sand dune distribution data and Ed Rowe for suggesting the use of the 30-year window. The nitrogen deposition data are freely available through the Air Pollution Information System website (http://www.apis.ac.uk/).

199 
Armitage HF, Britton AJ, van der Wal R, et al. 2014. The relative importance of nitrogen deposition as a driver of racomitrium heath species composition and richness across europe. Biological Conservation 171: 224-231.

Averis A, Averis, B., Birks, J., Horsfield, D., Thompson, D., Yeo, M. 2004. Illustrated guide to british upland vegetation. Joint Nature Conservation Committee.

Basto S, Thompson K, Phoenix G, et al. 2015. Long-term nitrogen deposition depletes grassland seed banks. Nature Communications 6: 6185. RIVM. 2011. Review and revision of empirical critical loads and dose-response relationships : Proceedings of an expert workshop, noordwijkerhout, 23-25 june 2010. The Netherlands. Bobbink R, Hicks K, Galloway J, et al. 2010. Global assessment of nitrogen deposition effects on terrestrial plant diversity: A synthesis. Ecological Applications 20: 30-59.

Carfrae JA, Sheppard L, Raven JA, et al. 2004. Early effects of atmospheric ammonia deposition on calluna vulgaris (I.) hull growing on an ombrotrophic peat bog. Water, Air, \& Soil Pollution: Focus 4: 229-239.

DEFRA. 2011. Biodiversity 2020: A strategy for england's wildlife and ecosystem services. London: Department of Environment Food and Rural Affairs.

Dise NB, Ashmore MR, Belyazid S, et al. Sutton M (Ed). 2011. Nitrogen as a threat to european terrestrial biodiversity. In: The european nitrogen assessment: Sources, effects and policy perspectives. Cambridge University Press.

Dore A, Vieno $\mathrm{M}$, Tang $\mathrm{Y}$, et al. 2007. Modelling the atmospheric transport and deposition of sulphur and nitrogen over the united kingdom and assessment of the influence of $\mathrm{sO}_{2}$ emissions from international shipping. Atmospheric Environment 41: 2355-2367.

Dragosits U, Carnell, E., Misselbrook, T., Stevens, C., Jones, L., Rowe, E., Hall, J., Dise, N., Dore, A., Tomlinson, S., Sheppard, L., O'Shea, L., Reis, S., Bealey, W., Braban, C., Smyntek, P., Sutton, M. 2015. Identification of potential 'remedies' for air pollution (nitrogen) impacts on designated sites (rapids). Report on defra project aq0834. Edinburgh: Centre for Ecology and Hydrology.

Duprè C, Stevens CJ, Ranke T, et al. 2010. Changes in species richness and composition in european acidic grasslands over the past 70 years: The contribution of cumulative atmospheric nitrogen deposition. Global Change Biology 16: 344-357.

Erisman JW, Galloway JN, Seitzinger S, et al. 2013. Consequences of human modification of the global nitrogen cycle. Philosophical Transactions of the Royal Society of London B: Biological Sciences 368: 20130116.

Field CD, Dise NB, Payne RJ, et al. 2014. The role of nitrogen deposition in widespread plant community change across semi-natural habitats. Ecosystems 17: 864-877.

Fowler D, O'Donoghue M, Muller JBA, et al. 2005. A chronology of nitrogen deposition in the uk between 1900 and 2000. Water, Air, \& Soil Pollution: Focus 4: 9-23.

Isbell F, Tilman D, Polasky S, et al. 2013. Low biodiversity state persists two decades after cessation of nutrient enrichment. Ecology Letters 16: 454-460.

Jones L, Stevens C, Rowe EC, et al. 2017. Can on-site management mitigate nitrogen deposition impacts in non-wooded habitats? Biological Conservation:

Lamarque J-F, Dentener F, McConnell J, et al. 2013. Multi-model mean nitrogen and sulfur deposition from the atmospheric chemistry and climate model intercomparison project (accmip): Evaluation historical and projected changes. Atmospheric Chemistry and Physics 13: 7997-8018. Maskell LC, Smart SM, Bullock JM, et al. 2010. Nitrogen deposition causes widespread loss of species richness in british habitats. Global Change Biology 16: 671-679.

Payne RJ, Caporn SJ, Field CD, et al. 2014. Heather moorland vegetation and air pollution: A comparison and synthesis of three national gradient studies. Water, Air, \& Soil Pollution 225: 1-13. Payne RJ, Dise NB, Stevens CJ, et al. 2013. Impact of nitrogen deposition at the species level. Proceedings of the National Academy of Sciences 110: 984-987. 
RoTAP. 2012. Review of transboundary air pollution (rotap): Acidification, eutrophication, ground level ozone and heavy metals in the uk. Centre for Ecology and Hydrology.

Rowe E, Jones L, Dise N, et al. 2016. Metrics for evaluating the ecological benefits of decreased nitrogen deposition. Biological Conservation: Smith RI, Fowler D, Sutton MA, et al. 2000. Regional estimation of pollutant gas dry deposition in the uk: Model description, sensitivity analyses and outputs. Atmospheric Environment 34: 3757-3777. Stevens CJ, Dise NB, Mountford JO, et al. 2004. Impact of nitrogen deposition on the species richness of grasslands. Science 303: 1876-1879. Storkey J, Macdonald AJ, Poulton PR, et al. 2015. Grassland biodiversity bounces back from longterm nitrogen addition. Nature 528: 401-404. Sutton M, Dragosits U, Geels C, et al. 2015. Review on the scientific underpinning of calculation of ammonia emission and deposition in the netherlands. Amsterdam: Government of the Netherlands. Sutton MA, Howard CM, Erisman JW, et al. 2011. The european nitrogen assessment: Sources, effects and policy perspectives. Cambridge University Press. Sutton MA, Oenema O, Erisman JW, et al. 2011. Too much of a good thing. Nature 472: 159-161. Tilman D and Isbell F. 2015. Biodiversity: Recovery as nitrogen declines. Nature 528: 336-337. United Nations. 2015. Transforming our world: The 2030 agenda for sustainable development. A/res/70/1. New York: United Nations. 
271 Figure 1. Projected species richness for 2015 for five widely-distributed habitats across Great Britain.

272 Figure based on the 30-year lagged response scenario. Shown is the mean species richness of all

273 habitats in each cell, scaled to $100 \%$ species richness in the absence of $\mathrm{N}$ deposition. Note that there

274 are no data for south-east England due to a low abundance of $\mathrm{N}$-sensitive semi-natural habitats: this

275 region is dominated by agricultural systems and/or habitats on calcareous soils. 


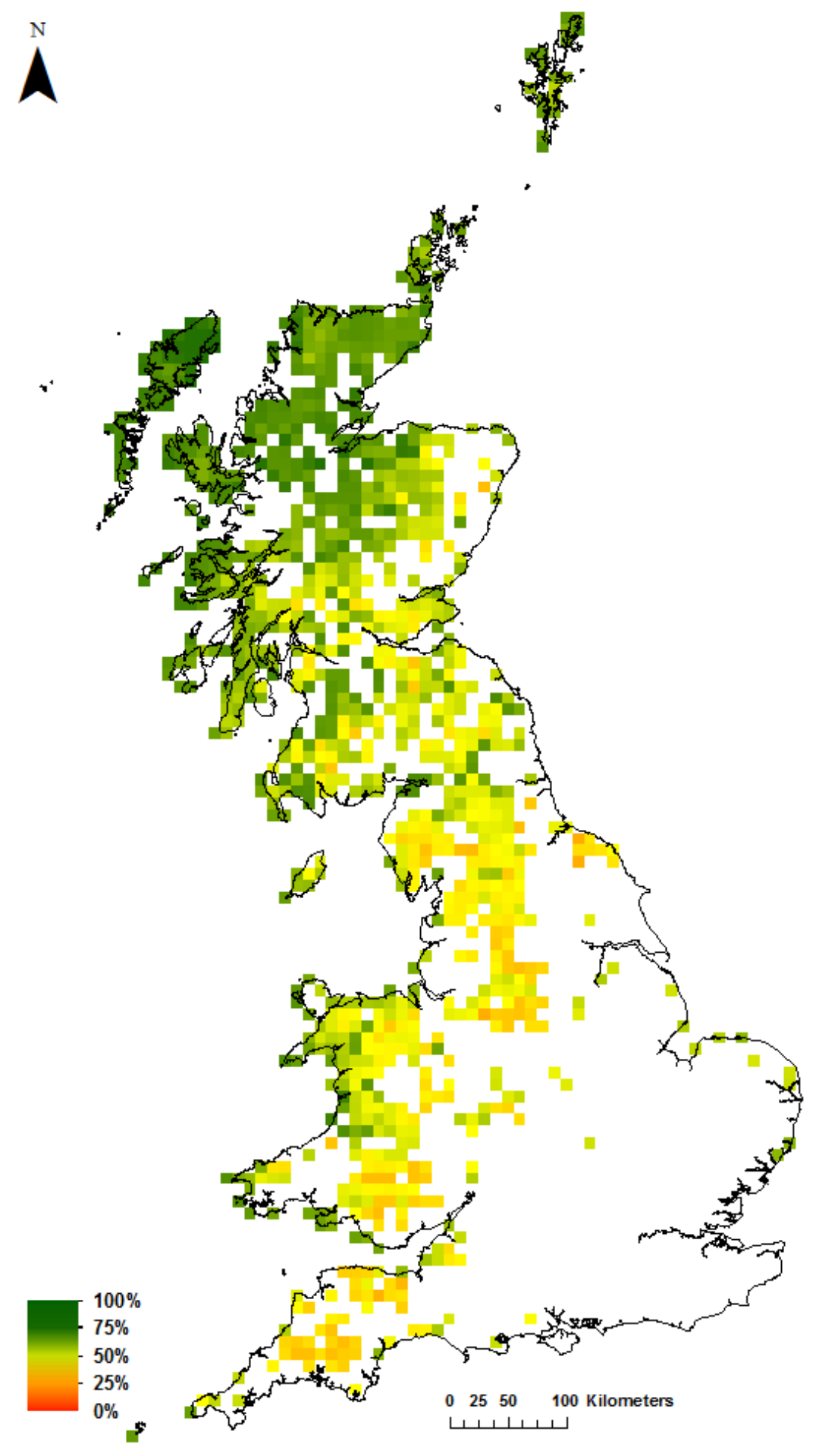

277 Figure 2. Projections of change in overall mean species richness due to $\mathrm{N}$ deposition across the five 278 habitats for 1900-2030 on the basis of a) instant, b) cumulative and c) lagged response scenarios. 279 Results show projections and estimated uncertainties based on regression $95 \%$ confidence bands 

(CE), $10 \%$ or $30 \%$ reduction above expectations $(\% 10, \% 30)$, and reduction to the critical load (CL).
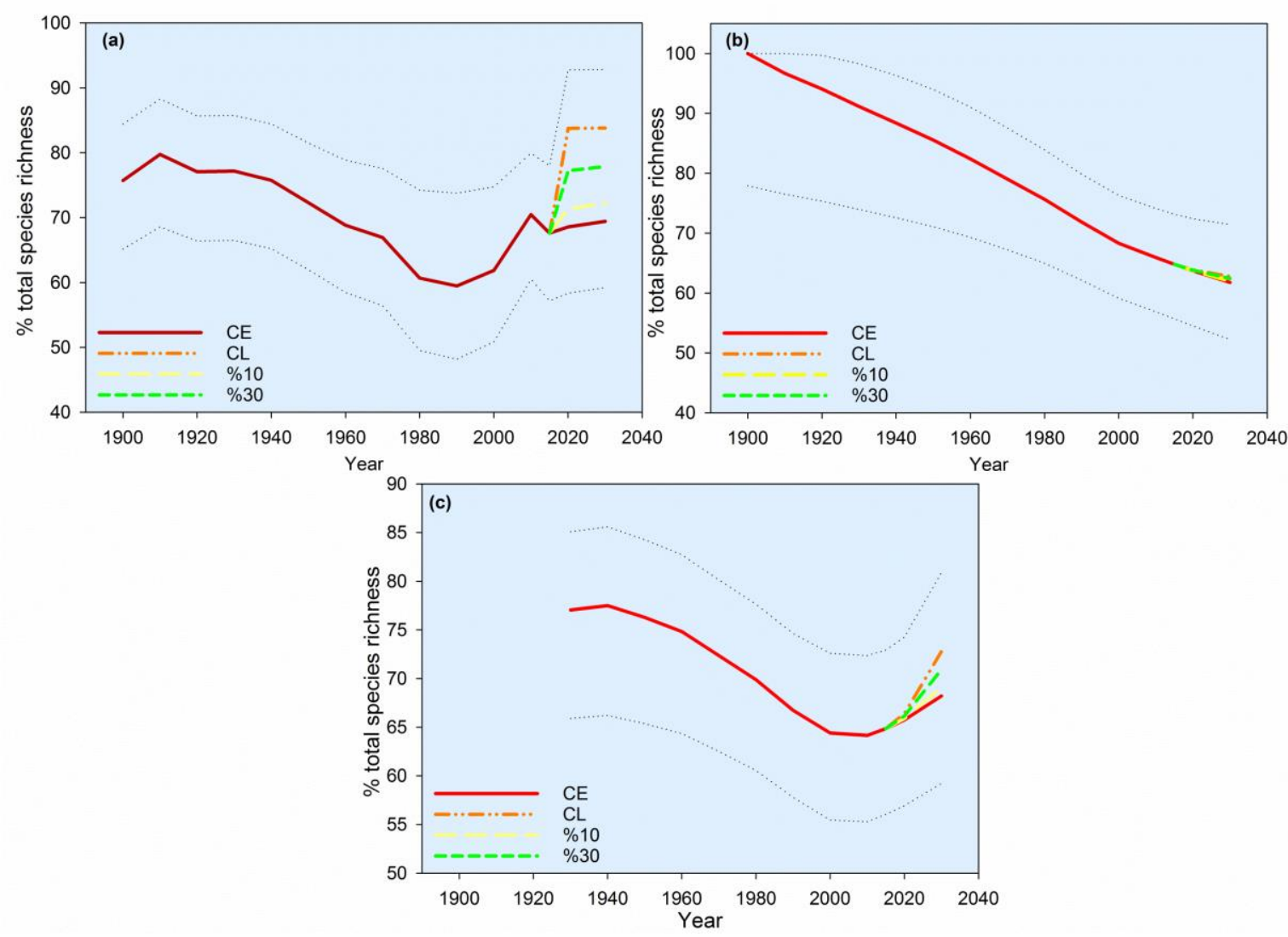

Table 1. Predictions of mean species richness (as a percentage of expected species richness in the absence of $\mathrm{N}$ deposition) in Great Britain across five habitats for 2030 using three response scenarios and four $\mathrm{N}$ deposition scenarios. Figures in parentheses show uncertainties in predictions based on $95 \%$ confidence bands of the underlying regressions. 
292 Table 1. Predictions of mean species richness (as a percentage of expected species richness in the 293 absence of $\mathbf{N}$ deposition) in Great Britain across five habitats for 2030 using three response scenarios 294 and four $\mathrm{N}$ deposition scenarios. Figures in parentheses show uncertainties in predictions based on $29595 \%$ confidence bands of the underlying regressions.

\begin{tabular}{|l|c|c|c|c|}
\hline \multirow{2}{*}{$\begin{array}{c}\text { Response to N } \\
\text { deposition }\end{array}$} & \multicolumn{3}{|c|}{ Predicted mean \% species richness for 2030 (and uncertainty) based on: } \\
\cline { 2 - 5 } & $\begin{array}{c}\text { Current } \\
\text { expectations (CE). }\end{array}$ & $\begin{array}{c}10 \% \text { reduction } \\
\text { above } \\
\text { expectation } \\
(\% 10) .\end{array}$ & $\begin{array}{c}\text { 30\% reduction } \\
\text { above } \\
\text { expectation } \\
(\% 30) .\end{array}$ & $\begin{array}{c}\text { Deposition } \\
\text { reduction to } \\
\text { critical load (CL). }\end{array}$ \\
\hline Instant & $69.4(59.2-79.4)$ & $72.2(62.1-81.5)$ & $77.9(67.3-86.7)$ & $83.8(71.7-92.9)$ \\
\hline Lagged & $68.2(59.2-76.1)$ & $69.1(60.0-76.9)$ & $70.9(61.5-78.8)$ & $72.7(63.2-80.9)$ \\
\hline Cumulative & $61.8(52.2-71.0)$ & $62.0(52.5-71.1)$ & $62.4(53.1-71.4)$ & $62.8(53.7-71.5)$ \\
\hline
\end{tabular}

296

297

298

299

300 
Total inorganic nitrogen deposition was modelled using the UK's national pollutant deposition models. Different forms and deposition pathways of $\mathrm{N}$ (e.g. oxidised vs reduced, wet vs dry) can have different ecological impacts (Sheppard, et al. 2011, Van den Berg, et al. 2008), however at a national scale total inorganic $\mathrm{N}$ deposition is a well-defined measure of $\mathrm{N}$ load that integrates the impacts of these different $\mathrm{N}$ forms and species. Past and present $\mathrm{N}$ deposition was estimated using the Centre for Ecology and Hydrology Concentration-Based Estimated Deposition model (C-BED (Smith, et al. 2000)). C-BED predicts $\mathrm{N}$ deposition for grid cells $(5 \times 5 \mathrm{~km}$; aggregated here to $10 \times 10 \mathrm{~km}$ to match vegetation data) on the basis of monitored atmospheric concentrations and climate data. As C-BED is based on measured data for the past to assess impacts into the future we used the process-based Fine Resolution Atmospheric Multi-pollutant Exchange (FRAME) model (Dore, et al. 2007, Fournier, et al. 2004, Fournier, et al. 2005). FRAME is calibrated to C-BED results to generate a self-consistent time series of nitrogen deposition and the two are frequently used in tandem. Comparisons to monitored data and model inter-comparisons show that FRAME performs reasonably well (Chemel, et al. 2011, Dore, et al. 2015, Smith, et al. 2000) and both CBED and FRAME are widely employed in a variety of science and policy contexts. To define the 'current expectations' (CE) scenario for future deposition we use FRAME predictions of total N deposition for 2020 and 2030 based on predicted trends in agricultural and industrial $\mathrm{N}$ emissions by the UK Department of Environment, Food and Rural Affairs (DEFRA). Scenarios of $10 \%$ and $30 \% \mathrm{~N}$ deposition reductions (relative to the CE scenario) assume major national-scale action is taken to produce additional $\mathrm{N}$ emissions reductions and that these reductions are implemented evenly across the UK between 2015 and 2020 and maintained thereafter. The fourth scenario assumes highly localised action to reduce $\mathrm{N}$ deposition to the lower limit of the critical load (CL) range (Bobbink and Hettelingh 2011) for the most sensitive of the habitats we consider in each grid cell. We model this reduction to occur progressively between 2015 and 2020 and for $\mathrm{N}$ deposition to be maintained at or below the critical load to 2030.

Reconstructing spatial trends in $\mathrm{N}$ deposition for the non-recent past is complicated since reliable atmospheric deposition monitoring for the UK only commenced in the 1980s (Fowler, et al. 2005). However, historical data for important variables such as farm animal numbers and coal consumption are available, along with limited $\mathrm{N}$ deposition data. Fowler, et al. (2005) have used this information to establish a national-scale deposition chronology and then hind-cast $\mathrm{N}$ deposition from 1900 by rescaling contemporary deposition patterns. This approach has been widely used to calculate historical trends in $\mathrm{N}$ deposition and total cumulative $\mathrm{N}$ deposition in Great Britain and at a European scale (Duprè, et al. 2010, Payne 2014, Phoenix, et al. 2012). We adopt this methodology here using C-BED data from 1996-1998 as a baseline to calculate total $\mathrm{N}$ deposition for each grid cell for the $20^{\text {th }}$ century, with 1900 selected as the start-point to span the total era of direct anthropogenic $\mathrm{N}$ fixation (1913 to present). We combine these hind-casted results with C-BED data for the current period of monitoring and predictions to 2030 based on FRAME to give grid cellspecific deposition chronologies as a self-consistent time series. 
343 To relate species richness to $\mathrm{N}$ deposition we use empirical response functions. We use previous surveys of habitats along national-scale gradients of $\mathrm{N}$ deposition to derive regression equations that characterise relationships between plant communities and $\mathrm{N}$ deposition. An alternative would be to use relationships based on $\mathrm{N}$-addition experiments (Hettelingh, et al. 2008). However, experimental studies are often limited by small plot sizes, high treatment doses, unrealistic treatment frequency, short duration and high background levels of $\mathrm{N}$ deposition, making both temporal and spatial extrapolation extremely problematic. Relationships based on targeted surveys along national $\mathrm{N}$ deposition gradients are now widely-accepted as characterising the relationship between plant communities and N deposition (Caporn, et al. 2014, Payne, et al. 2014, Stevens, et al. 2011).

We restricted our study to five vegetation communities that are widespread and known to be sensitive to $\mathrm{N}$ deposition, and for which targeted survey datasets are available across Great Britain: acid grassland (National Vegetation Classification U4), sand dune (SD8, SD12), blanket bog (M18, M19), upland heath ( $\mathrm{H} 12$ ) and lowland heath (H8- H10). We used the dataset of Stevens, et al. (2004) for acid grassland and the datasets of Field, et al. (2014) for the other habitats. We focus on species richness as a meaningful, easily-quantified, and well-understood measure of biodiversity that has been widely used in pollution impact studies (Maskell, et al. 2010, Stevens, et al. 2004). We calculate species richness as the number of species per $2 \times 2 \mathrm{~m}$ quadrat averaged over five quadrats. In all of these habitats previous research has shown that there is a negative correlation between $\mathrm{N}$ deposition and species richness which cannot be adequately explained by other variables such as climate or local site conditions (e.g. pH, soil organic matter, grazing intensity)(Field, et al. 2014, Stevens, et al. 2004). On this basis our models solely consider $\mathrm{N}$ deposition and thereby assume any co-variance with other environmental drivers remains constant.

Regression models relating species richness to current $\mathrm{N}$ deposition have been previously presented by Field, et al. (2014) and Stevens, et al. (2004) and were re-calculated here using a consistent approach. To allow flexibility in the form of the regression we considered a sequence of polynomials of increasing complexity. To avoid over-fitting we only used more complex models where they resulted in a significant improvement in fit ( $\mathrm{F}$-test, $\mathrm{P}<0.05)$; in practise all selected models were either linear (the majority) or quadratic (WebTable 2). Using current $\mathrm{N}$ deposition for prediction implies that when $\mathrm{N}$ deposition falls there will be an instant recovery of species richness. As there are many reasons to believe that this will not be the case we also produced regressions based on two alternative $\mathrm{N}$ deposition metrics. Firstly, to encompass the possibility that $\mathrm{N}$ deposition may force habitats across a 'tipping point' (Isbell, et al. 2013) we considered cumulative $\mathrm{N}$ deposition since 1900. Using this metric assumes that impacts accumulate over time with no possibility for recovery however greatly $\mathrm{N}$ deposition is reduced. Reality may lie somewhere between these extremes of 'instant recovery' and 'no recovery ever' with some species recovering quickly but others recovering very slowly. To encompass this 'lagged impact/lagged recovery' scenario we also considered $\mathrm{N}$ deposition accumulated over the previous thirty years. We selected 30 years as the duration of this moving window following a recent compilation of expert opinion by UK air pollution scientists (Rowe, et al. 2016). For each habitat we therefore produced three alternative regressions based on each of our three $\mathrm{N}$ deposition metrics (WebTable 2). Current, cumulative and 30-year 
the three metrics or any one of the three sets of results. Instead we propose that they are all plausible and can be viewed as representing the range of alternative possible outcomes.

Our models are based solely on the data and do not make any a priori assumptions about how species richness should respond to $\mathrm{N}$ deposition. We recognise that there will be some level of nonanthropogenic nitrogen deposition (due to lightning, volcanism etc.) to which ecosystems will be adapted, but in industrialised regions such as the United Kingdom this will be dwarfed by anthropogenic emission (Galloway, et al. 2004) and can safely be ignored.

\section{$\underline{\text { Vegetation distribution }}$}

To quantify the spatial distribution of our five target habitats we used the UK Joint Nature Conservation Committee, extended National Vegetation Classification Dataset (NVC (Averis 2004, Rodwell 1991)), supplemented by additional data for sand dunes (Dr Laurence Jones, CEH Bangor). With more than 35,000 records, the NVC dataset is probably the largest survey-based vegetation distribution dataset available for any country. The dataset records the presence of an NVC community within a $10 \times 10 \mathrm{~km}$ grid cell based on site visits by expert surveyors. This allows us to have confidence that these specific communities are present, and obviates the need for extrapolation across communities which would be required for alternative land cover datasets based on remote sensing. As the dataset combines information from studies made over several decades the distribution of the vegetation communities remains static over time in all our models.

Our $\mathrm{N}$ deposition modelling allowed us to produce deposition chronologies for every grid cell identified as containing one of our five target habitats. To these grid cell chronologies we applied our habitat-specific response functions to predict changes in species richness for each time step. We repeated this process three times using each of: current, cumulative 1900- and thirty year cumulative $\mathrm{N}$ deposition data as the driver of change. To integrate results across habitats we expressed the output on a relative scale as a percentage of species richness in the absence of $\mathrm{N}$ deposition (i.e. the $Y$ intercept) with all results constrained to be $100>0 \%$. We mapped the results and by summing across all grid squares and habitat types thereby calculated a figure for percentage loss in national biodiversity. We derived estimates of uncertainty for these figures by using the $95 \%$ confidence bands of the regressions to give maximum and minimum estimates for each grid cell.

In interpreting the results it should be borne in mind that we focus on five habitats which, while widespread and of conservation importance, are all known to be sensitive to $\mathrm{N}$ deposition in terms of species richness. Our results may not apply equally to all other habitats. Our models also do not consider the effect of any drivers other than $\mathrm{N}$ deposition. We do not attempt to model change in other drivers of biodiversity change such as landuse or climate change. Our approach is the best currently practicable but large underlying uncertainties mean that results should be viewed primarily as a means to explore plausible scenarios. 
WebFigure 1. Schematic diagram demonstrating the principles of our approach. In the first stage (i) national surveys of plant species richness are conducted spanning air pollution gradients (these have been previously published); in the second stage (ii) the relationship between species richness and $\mathrm{N}$ deposition is modelled using regression; in the third stage (iii) these regression models are applied to vegetation maps and national $\mathrm{N}$ deposition data to predict national impacts on species richness (iv). Stages iii and iv are repeated for multiple time steps and the entire process is repeated using current, cumulative and 30 year cumulative $\mathrm{N}$ deposition to give three sets of results (WebFigure 2).

i)
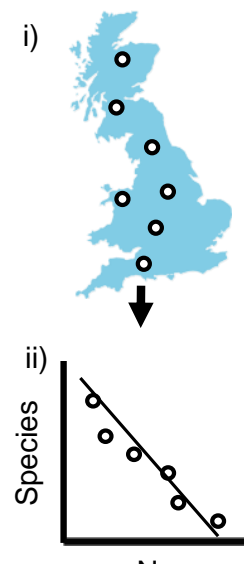

$\mathrm{N}$

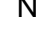

iii)

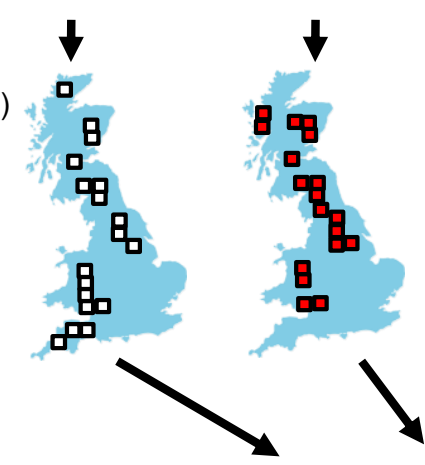

iv)

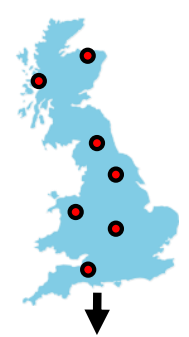

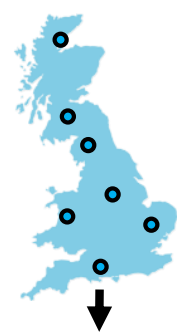
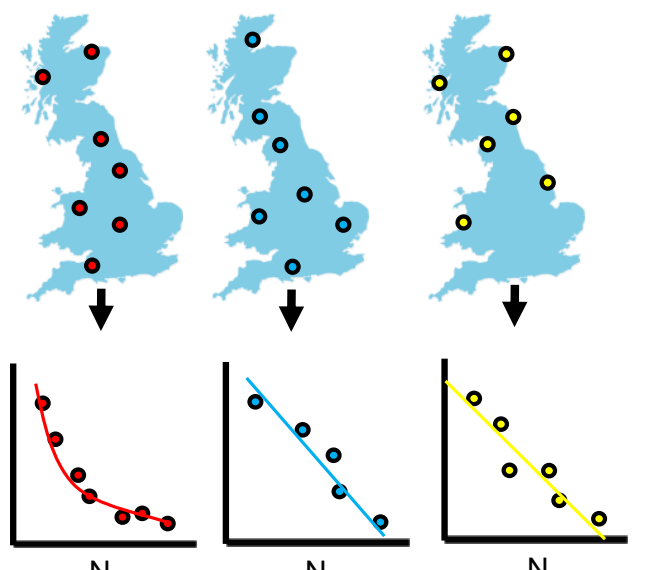

$\mathrm{N}$
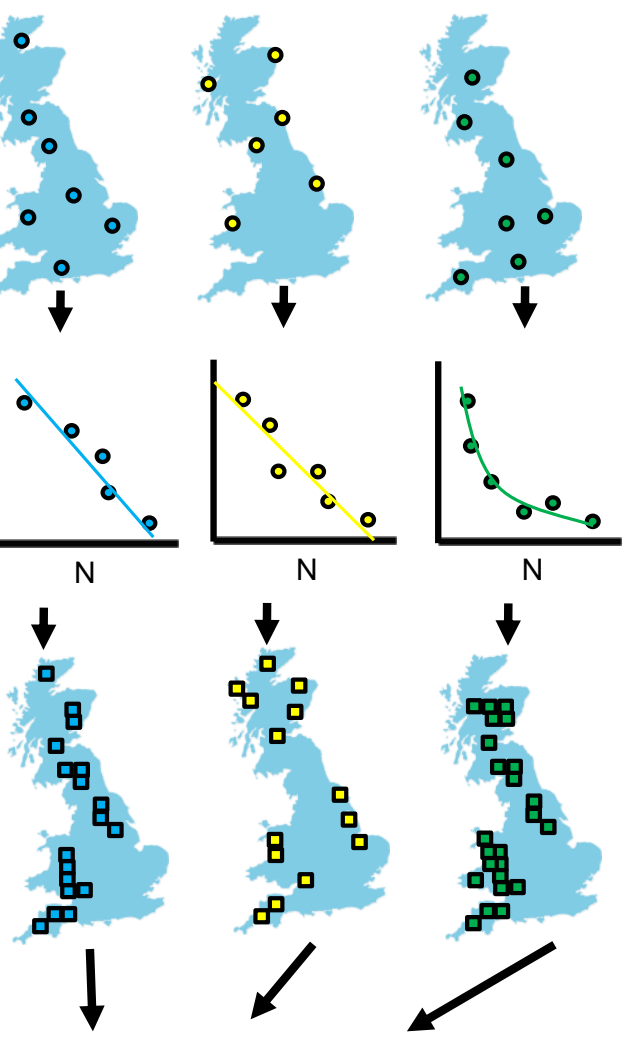

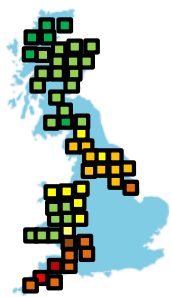


430 WebFigure 2. Hind-casted change in mean species richness by habitat based on a) instant, b) cumulative and c) 30-year lagged response to $\mathrm{N}$ deposition.
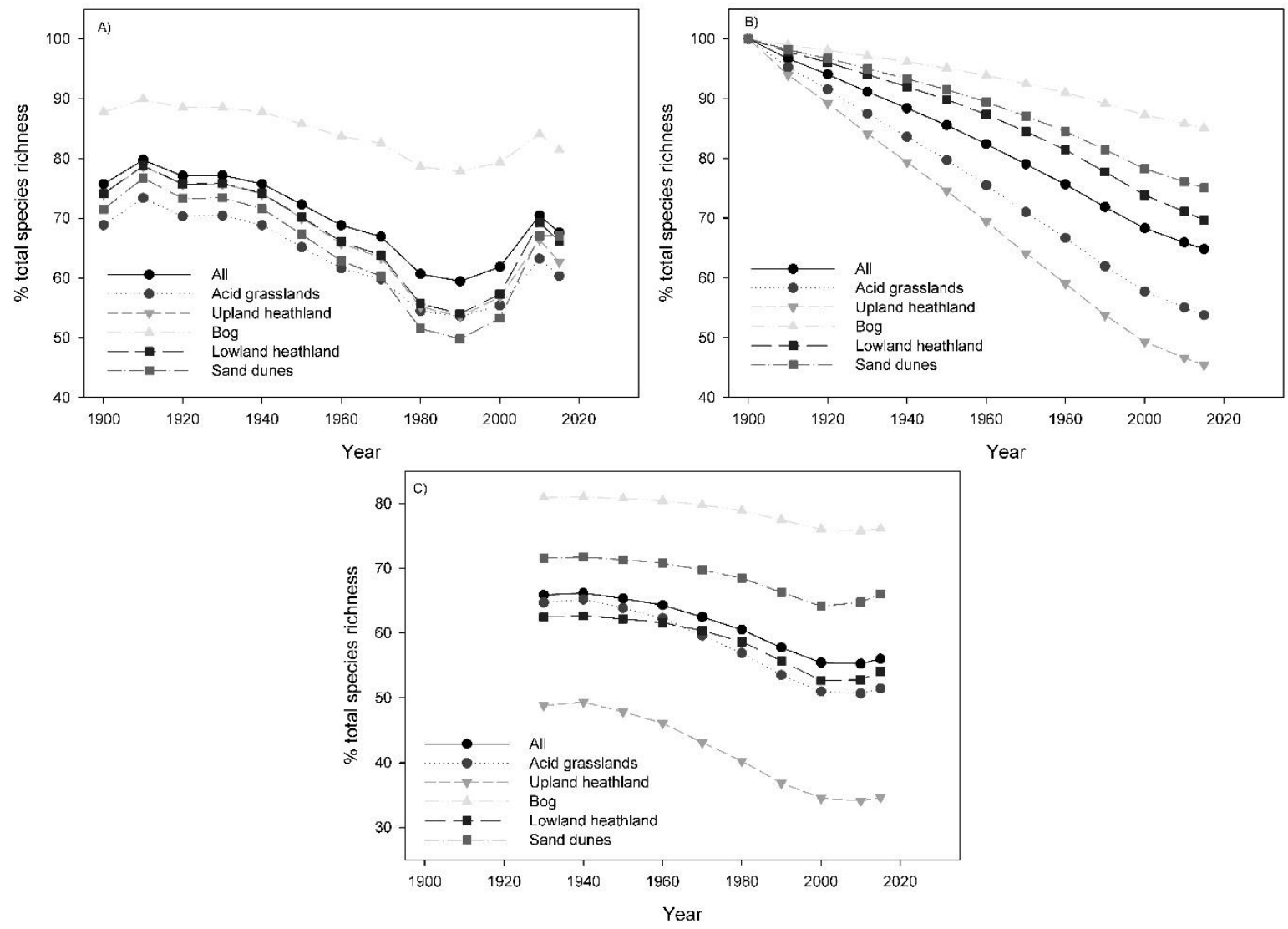

cumulative and c) 30-year lagged response to $\mathrm{N}$ deposition scenarios.

A)

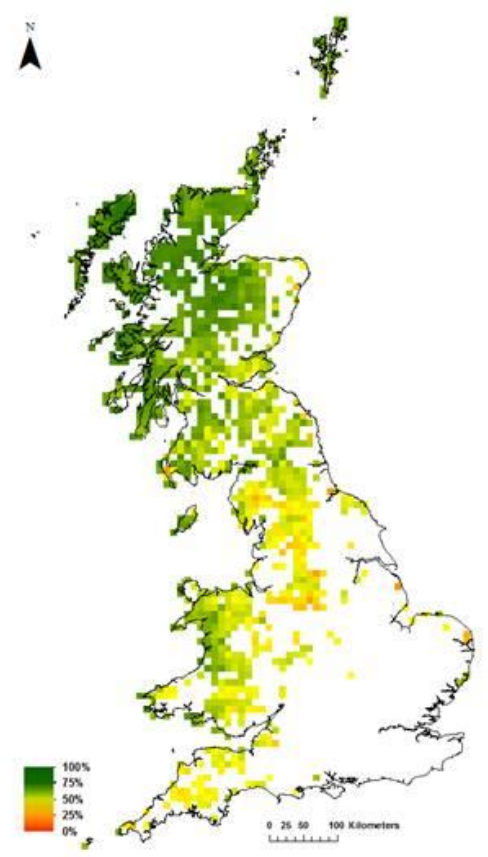

B)

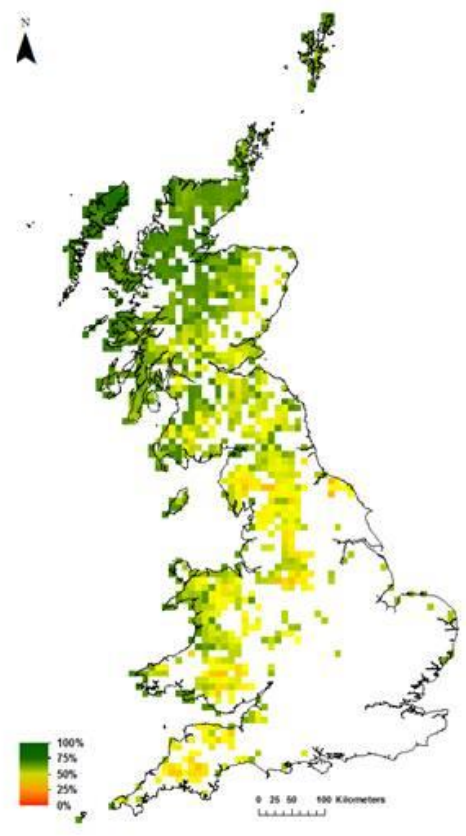

C)

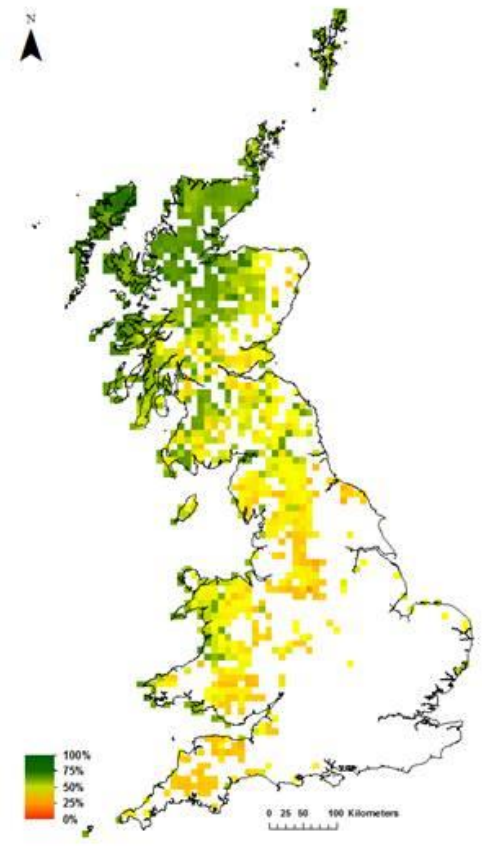


WebTable 1. Total deposition reduction required to reach same mean species richness by blanket cuts versus reduction to critical load.

\begin{tabular}{cc}
\hline $\begin{array}{c}\text { Response to } \mathbf{N} \\
\text { deposition }\end{array}$ & $\begin{array}{c}\text { Proportion deposition reduction } \\
\text { required by blanket cuts } \\
\text { versus reduction to critical } \\
\text { load }\end{array}$ \\
\hline Instant & 0.96 \\
Lagged & 0.93 \\
\hline Cumulative & 0.86 \\
\hline
\end{tabular}

442

WebTable 2. $\mathrm{R}^{2}$ values showing fit of models based on alternative metrics of $\mathrm{N}$ deposition. Bestfitting alternatives shown in bold. Selected models were all linear with the exception of those with values underlined, which were quadratic.

\begin{tabular}{lccc}
\hline & Current & Lagged & Cumulative \\
\hline Acid grasslands & $\underline{0.63}$ & $\underline{0.63}$ & $\underline{\mathbf{0 . 6 3}}$ \\
Upland heaths & 0.39 & $\underline{\mathbf{0 . 5 8}}$ & $\underline{0.58}$ \\
Lowland heaths & 0.13 & $\mathbf{0 . 2 0}$ & 0.19 \\
Bogs & $\mathbf{0 . 1 9}$ & 0.17 & 0.15 \\
Sand dunes & $\mathbf{0 . 4 1}$ & 0.30 & 0.30 \\
\hline
\end{tabular}



scenario.

449

Supplementary Video File.wmv

450 
452 Armitage HF, Britton AJ, van der Wal R, et al. 2014. The relative importance of nitrogen deposition as 453 a driver of racomitrium heath species composition and richness across europe. Biological

454 Conservation 171: 224-231.

455 Averis A, Averis, B., Birks, J., Horsfield, D., Thompson, D., Yeo, M. 2004. Illustrated guide to british 456 upland vegetation. Joint Nature Conservation Committee.

457 Basto S, Thompson K, Phoenix G, et al. 2015. Long-term nitrogen deposition depletes grassland seed 458 banks. Nature Communications 6: 6185. RIVM. 2011. Review and revision of empirical critical loads and dose-response relationships : Proceedings of an expert workshop, noordwijkerhout, 23-25 june 2010. The Netherlands. Bobbink R, Hicks K, Galloway J, et al. 2010. Global assessment of nitrogen deposition effects on terrestrial plant diversity: A synthesis. Ecological Applications 20: 30-59.

Caporn SJ, Carroll JA, Dise NB, et al. 2014. Impacts and indicators of nitrogen deposition in moorlands: Results from a national pollution gradient study. Ecological Indicators 45: 227-234. Carfrae JA, Sheppard L, Raven JA, et al. 2004. Early effects of atmospheric ammonia deposition on calluna vulgaris (I.) hull growing on an ombrotrophic peat bog. Water, Air, \& Soil Pollution: Focus 4: 229-239.

Chemel C, Sokhi RS, Dore AJ, et al. 2011. Predictions of uk regulated power station contributions to regional air pollution and deposition: A model comparison exercise. Journal of the Air \& Waste Management Association 61: 1236-1245.

DEFRA. 2011. Biodiversity 2020: A strategy for england's wildlife and ecosystem services. London: Department of Environment Food and Rural Affairs.

Dise NB, Ashmore MR, Belyazid S, et al. Sutton M (Ed). 2011. Nitrogen as a threat to european terrestrial biodiversity. In: The european nitrogen assessment: Sources, effects and policy perspectives. Cambridge University Press.

Dore A, Vieno M, Tang Y, et al. 2007. Modelling the atmospheric transport and deposition of sulphur and nitrogen over the united kingdom and assessment of the influence of $\mathrm{sO}_{2}$ emissions from international shipping. Atmospheric Environment 41: 2355-2367.

Dore AJ, Carslaw DC, Braban C, et al. 2015. Evaluation of the performance of different atmospheric chemical transport models and inter-comparison of nitrogen and sulphur deposition estimates for the uk. Atmospheric Environment 119: 131-143.

Dragosits U, Carnell, E., Misselbrook, T., Stevens, C., Jones, L., Rowe, E., Hall, J., Dise, N., Dore, A., Tomlinson, S., Sheppard, L., O'Shea, L., Reis, S., Bealey, W., Braban, C., Smyntek, P., Sutton, M. 2015. Identification of potential 'remedies' for air pollution (nitrogen) impacts on designated sites (rapids). Report on defra project aq0834. Edinburgh: Centre for Ecology and Hydrology.

Duprè C, Stevens CJ, Ranke T, et al. 2010. Changes in species richness and composition in european acidic grasslands over the past 70 years: The contribution of cumulative atmospheric nitrogen deposition. Global Change Biology 16: 344-357.

Erisman JW, Galloway JN, Seitzinger S, et al. 2013. Consequences of human modification of the global nitrogen cycle. Philosophical Transactions of the Royal Society of London B: Biological Sciences 368: 20130116.

Field CD, Dise NB, Payne RJ, et al. 2014. The role of nitrogen deposition in widespread plant community change across semi-natural habitats. Ecosystems 17: 864-877.

Fournier N, Dore A, Vieno M, et al. 2004. Modelling the deposition of atmospheric oxidised nitrogen and sulphur to the united kingdom using a multi-layer long-range transport model. Atmospheric Environment 38: 683-694.

Fournier N, Weston KJ, Dore AJ, et al. 2005. Modelling the wet deposition of reduced nitrogen over the british isles using a lagrangian multi-layer atmospheric transport model. Quarterly Journal of the Royal Meteorological Society 131: 703-722.

Fowler D, O'Donoghue M, Muller JBA, et al. 2005. A chronology of nitrogen deposition in the uk between 1900 and 2000. Water, Air, \& Soil Pollution: Focus 4: 9-23. 
502 Galloway JN, Dentener FJ, Capone DG, et al. 2004. Nitrogen cycles: Past, present, and future.

503 Biogeochemistry 70: 153-226.

504 Hettelingh J-P, Posch M, Slootweg J, et al. 2008. Tentative dose-response function applications for integrated assessment. CCE status report: 89. Isbell F, Tilman D, Polasky S, et al. 2013. Low biodiversity state persists two decades after cessation of nutrient enrichment. Ecology Letters 16: 454-460. Jones L, Stevens C, Rowe EC, et al. 2017. Can on-site management mitigate nitrogen deposition impacts in non-wooded habitats? Biological Conservation: Lamarque J-F, Dentener F, McConnell J, et al. 2013. Multi-model mean nitrogen and sulfur deposition from the atmospheric chemistry and climate model intercomparison project (accmip): Evaluation historical and projected changes. Atmospheric Chemistry and Physics 13: 7997-8018. Maskell LC, Smart SM, Bullock JM, et al. 2010. Nitrogen deposition causes widespread loss of species richness in british habitats. Global Change Biology 16: 671-679.

Payne R. 2014. The exposure of british peatlands to nitrogen deposition, 1900-2030. Mires and Peat 14: 1-9.

Payne RJ, Caporn SJ, Field CD, et al. 2014. Heather moorland vegetation and air pollution: A comparison and synthesis of three national gradient studies. Water, Air, \& Soil Pollution 225: 1-13. Payne RJ, Dise NB, Stevens CJ, et al. 2013. Impact of nitrogen deposition at the species level. Proceedings of the National Academy of Sciences 110: 984-987.

Phoenix GK, Emmett BA, Britton AJ, et al. 2012. Impacts of atmospheric nitrogen deposition: Responses of multiple plant and soil parameters across contrasting ecosystems in long-term field experiments. Global Change Biology 18: 1197-1215.

Rodwell JS. 1991. British plant communities. Cambridge University Press.

RoTAP. 2012. Review of transboundary air pollution (rotap): Acidification, eutrophication, ground level ozone and heavy metals in the uk. Centre for Ecology and Hydrology.

Rowe E, Jones L, Dise N, et al. 2016. Metrics for evaluating the ecological benefits of decreased nitrogen deposition. Biological Conservation:

Rowe E, Jones L, Dise N, et al. 2016. Metrics for evaluating the ecological benefits of decreased nitrogen deposition. Biological Conservation:

Sheppard L, Leith ID, Mizunuma T, et al. 2011. Dry deposition of ammonia gas drives species change faster than wet deposition of ammonium ions: Evidence from a long-term field manipulation. Global Change Biology 17: 3589-3607.

Smith RI, Fowler D, Sutton MA, et al. 2000. Regional estimation of pollutant gas dry deposition in the uk: Model description, sensitivity analyses and outputs. Atmospheric Environment 34: 3757-3777.

Stevens CJ, Dise NB, Mountford JO, et al. 2004. Impact of nitrogen deposition on the species richness of grasslands. Science 303: 1876-1879.

Stevens CJ, Manning P, Van den Berg LJL, et al. 2011. Ecosystem responses to reduced and oxidised nitrogen inputs in european terrestrial habitats. Environmental Pollution 159: 665-676.

Storkey J, Macdonald AJ, Poulton PR, et al. 2015. Grassland biodiversity bounces back from longterm nitrogen addition. Nature 528: 401-404.

Sutton M, Dragosits U, Geels C, et al. 2015. Review on the scientific underpinning of calculation of ammonia emission and deposition in the netherlands. Amsterdam: Government of the Netherlands. Sutton MA, Howard CM, Erisman JW, et al. 2011. The european nitrogen assessment: Sources, effects and policy perspectives. Cambridge University Press.

Sutton MA, Oenema O, Erisman JW, et al. 2011. Too much of a good thing. Nature 472: 159-161. Tilman D and Isbell F. 2015. Biodiversity: Recovery as nitrogen declines. Nature 528: 336-337. United Nations. 2015. Transforming our world: The 2030 agenda for sustainable development. A/res/70/1. New York: United Nations.

Van den Berg LL, Peters CJH, Ashmore MR, et al. 2008. Reduced nitrogen has a greater effect than oxidised nitrogen on dry heathland vegetation. Environmental Pollution 154: 359-369. 
553 